\title{
Screening of factors influencing the hydrolysis reaction of chicken leg cartilage with Protamex enzyme as a catalyst
}

\author{
Cuong V. Bui ${ }^{1 *}$, Kim Chi T. Nguyen ${ }^{1}$, \& Dong X. Bui ${ }^{2}$ \\ ${ }^{1}$ Department of Food Technology, Faculty of Chemical Engineering, University of Science and Technology, \\ The University of Da Nang, Da Nang, Vietnam \\ ${ }^{2}$ Department of Bio-Technology, Faculty of Chemical Engineering, University of Science and Technology, \\ The University of Da Nang, Da Nang, Vietnam
}

ARTICLE INFO
Research Paper
Received: May 29, 2020
Revised: July 10, 2020
Accepted: August 21, 2020

\section{Keywords}

Amino acid yield

Chicken cartilage

Hydrolysis reaction

Hydrolysis yield

Protamex enzyme

\section{${ }^{*}$ Corresponding author}

Bui Viet Cuong

Email: bvcuong@dut.udn.vn

\section{ABSTRACT}

The objective of this research was to use Protamex enzyme as a catalyst to hydrolyze chicken leg cartilage for production of amino acid hydrolysate. The proximate composition of chicken cartilage was analyzed. The results indicated that the major components in the dry matter of chicken leg cartilage were lipid (19.72 \pm 0.05\%) and protein (13.34 \pm $0.08 \%$ ). The main parameters affecting the hydrolysis reaction of chicken leg cartilage with Protamex enzyme were selected for investigation: reaction temperature $\left({ }^{\circ} \mathrm{C}\right), \mathrm{pH}$, enzyme ratio $(\%$, based on the weight of substrate), reaction time $(\mathrm{min})$, and the ratio of reaction volume $(\mathrm{v} / \mathrm{v})$. The significant difference was analyzed by ANOVA One-Way to identify the optimal point of each parameter toward amino acid yield. The results revealed that the hydrolysis degree and amino acid yield reached the maximal values of $22.93 \pm 4.01 \%$ and $30.25 \pm 1.86 \%$, respectively, when the reaction temperature, $\mathrm{pH}$, enzyme ratio, reaction time, and ratio of reaction volume $(\mathrm{v} / \mathrm{v})$ were $40^{\circ} \mathrm{C}, 4,0.52 \%, 40 \mathrm{~min}$, and $1 / 18$, respectively.

Cited as: Bui, C. V., Nguyen, K. C. T., \& Bui, D. X. (2020). Screening of factors influencing the hydrolysis reaction of chicken leg cartilage with Protamex enzyme as a catalyst. The Journal of Agriculture and Development 19(4), 73-79. 


\title{
Khảo sát các yếu tố ảnh hưởng đến phản ứng thủy phân sụn khớp chân gà với xúc tác enzyme Protamex
}

\author{
Bùi Viết Cường ${ }^{1 *}$, Nguyễn Thị Kim $\mathrm{Chi}^{1}{ }^{1}$ \& Bùi Xuân Đông ${ }^{2}$ \\ ${ }^{1}$ Bộ Môn Công Nghệ Thực Phẩm, Khoa Hóa, Trường Đại Học Bách Khoa, Đại Học Đà Nẵng, Đà Nẵng \\ ${ }^{2}$ Bộ Môn Công Nghệ Sinh Học, Khoa Hóa, Trường Đại Học Bách Khoa, Đại Học Đà Nẵng, Đà Nẵng
}

\section{THÔNG TIN BÀI BÁO}

Bài báo khoa học

Ngày nhận: 29/05/2020

Ngày chỉnh sửa: 10/07/2020

Ngày chấp nhận: 21/08/2020

\section{Từ khóa}

Enzyme Protamex

Hiệu suất thủy phân

Hiệu suất thu nhận axit amin

Phản ứng thủy phân

Sụn khớp chân gà

\section{*Tác giả liên hệ}

Bùi Viết Cường

Email: bvcuong@dut.udn.vn

\section{TÓM TẮT}

Nghiên cứu này được tiến hành với mục đích thủy phân sụn khớp chân gà với xúc tác enzyme Protamex nhằm thu axit amin. Thành phần hóa học của sụn khớp chân gà được phân tích, kết quả phân tích cho thấy hai thành phần chính trong chất khô của sụn khớp chân gà là lipid $(19,72 \pm 0,05 \%)$ và protein $(13,34 \pm 0,08 \%)$. Các yếu tố chính ảnh hưởng đến phản ứng thủy phân sụn khớp chân gà với xúc tác enzyme Protamex được lựa chọn để khảo sát: Nhiệt độ phản ứng $\left({ }^{\circ} \mathrm{C}\right)$, pH môi trường phản ứng, tỉ lệ enzyme (\%, dựa trên cơ chất), thời gian phản ứng (phút) và tỉ lệ thể tích môi trường phản ứng $(\mathrm{v} / \mathrm{v})$. Phân tích sự khác biệt có ý nghĩa được tiến hành với phương pháp ANOVA One-Way nhằm lựa chọn điều kiện tốt nhất cho phản ứng thủy phân. Hiệu suất thủy phân và hiệu suất thu nhận axit amin đạt giá trị lớn nhất lần lượt là $22,93 \pm 4,01 \%$ và $30,25 \pm 1,86 \%$ khi nhiệt độ phản ứng; pH môi trường phản ứng; tỉ lệ enzyme; thời gian phản ứng và tỉ lệ thể tích môi trường phản ứng thích hợp lần lượt là $40^{\circ} \mathrm{C} ; 4 ; 0,52 \%$; 40 phút và $1 / 18(\mathrm{v} / \mathrm{v})$.

\section{1. Đặt Vấn Đề}

Xử lý và chế biến phụ phẩm giết mổ gia cầm thành các sản phẩm có giá trị cao nhằm nâng cao hiệu quả kinh tế và giảm lượng chất thải rắn là thách thức lớn và thu hút sự quan tâm nghiên cứu của cộng đồng khoa học (Meeker, 2006). Đặc biệt trong bối cảnh hiện nay, nhu cầu về thịt gia cầm đang tăng lên trên thế giới và Việt Nam. Sản lượng thịt gà toàn cầu đã tăng $2 \%$ vào năm 2019 ; tương ứng với 97,8 triệu tấn; và xuất khẩu thịt gà toàn cầu tăng mạnh $4 \%$ vào năm 2019 ; tương ứng với 11,6 triệu tấn (Mangino, 2019). Công nghiệp giết mổ gia cầm đã thải ra môi trường một lượng lớn phụ phẩm hữu cơ: nội tạng, chân, đầu,.... Xử lý hiệu quả phụ phẩm giết mổ gia cầm sẽ có tác động tích cực đối với kinh tế và môi trường (Jay- athilakan \& ctv., 2012).

Sụn khớp chân gà có thành phần protein khá cao $(11,78 \pm 0,21 \%)$ (Araújo \& ctv., 2018) nhưng chỉ được sử dụng làm thức ăn chăn nuôi, phân bón hóa học hoặc các ngành công nghiệp hóa chất khác tại các nước phát triển. Tuy nhiên, tại các nước châu Á nói chung và Việt Nam nói riêng sụn khớp chân gà được sử dụng làm thực phẩm cho con người vì có giá trị dinh dưỡng lớn (Meeker, 2006). Đặc biệt sụn khớp chân gà có chứa nhiều thành phần có hoạt tính sinh học (collagen) cao và tốt cho sức khỏe xương khớp, có tác dụng xóa nếp nhăn trên da, làm mượt da và chống lão hóa (Nakano \& ctv., 1995; Luo \& ctv., 2002). Tuy nhiên, collagen phải được phân giải thành peptides hoặc axit amin để có thể hấp thụ được trong hệ thống tiêu hóa của con người và động vật do 
đó khả năng hấp thụ của protein (collagen) sẽ thấp hơn so với axit amin. Ngoài ra, trong một vài trường hợp protein không có khả năng tiêu hóa và hấp thụ hoàn toàn, phần còn sót lại sau quá trình tiêu hóa sẽ bị phân hủy và hình thành độc tố: amoniac, phenol, benzpyrol,... trong khi đó các axit amin có thể được hấp thụ hoàn toàn (Thureen, 2012).

Phản ứng thủy phân với xúc tác enzyme có nhiều ưu điểm hơn so với xúc tác phi enzyme như điều kiện phản ứng "nhẹ nhàng" hơn, giá trị dinh dưỡng của sản phẩm thủy phân cao hơn, enzyme có tính đặc hiệu do đó mức độ tinh khiết của sản phẩm thủy phân cao hơn vì không hình thành sản phẩm phụ (Wisuthiphaet \& ctv., 2016; Bui \& ctv., 2017). Enzyme Protamex được phép sử dụng trong thực phẩm theo qui định của $\mathrm{FAO}$ và WHO về phụ gia thực phẩm (JEFTA) và Bộ luật hóa chất thực phẩm (FCC) (Nguyen \& ctv., 2011; Bui \& ctv., 2017). Do đó, enzyme Protamex được sử dụng trong nghiên cứu này để thủy phân sụn khớp chân gà với mục đích thu nhận axit amin.

\section{Vật Liệu và Phương Pháp Nghiên Cứu}

\subsection{Sụn khớp chân gà}

Sụn khớp chân gà được cung cấp bởi Công ty TNHH TM \& DV Hoàng Phát - Đà Nẵng ở dạng đông lạnh, 1 kg/1 block. Sụn khớp chân gà được vận chuyển trong thùng xốp có khả năng giữ nhiệt và được bảo quản ở $-20^{\circ} \mathrm{C}$ sau khi vận chuyển về phòng thí nghiệm. Sụn khớp chân gà được rã đông bằng không khí tới $0^{\circ} \mathrm{C}$, rửa sạch và xay nhỏ bằng máy xay (ATS TS-102AL, Đài Loan), lựa chọn bằng sàng có kích thước $6 \mathrm{~mm}$. Nguyên liệu qua lưới sàng được chia nhỏ thành từng khối đựng trong các túi nilon kín có khối lượng 100 g, được bảo quản ở $-20^{\circ} \mathrm{C}$ cho những lần thí nghiệm tiếp theo.

\subsection{Enzyme và hóa chất}

Enzyme Protamex được cung cấp bởi công ty TNHH XNK vật tư khoa học quốc tế STECH International. Hoạt độ protease của enzyme Protamex là 38994,3 UI/g. Điều kiện tối ưu của enzyme Protamex là $\mathrm{pH}=5,5-7,5$; nhiệt độ từ 35 - $60^{\circ} \mathrm{C}$ (Liaset \& ctv., 2003). Nhiệt độ bảo quản tốt nhất của Protamex là $0-5^{\circ} \mathrm{C}$. Các hóa chất được sử dụng cho nghiên cứu có mức độ tinh khiết dùng cho phân tích.

\subsection{Phương pháp nghiên cứu}

\subsubsection{Quá trình thủy phân sụn khớp chân gà}

Sụn khớp chân gà $(5 \mathrm{~g})$ được trộn đều với xúc tác enzyme Protamex và $50 \mathrm{~mL}$ nước cất trong bình phản ứng Erlenmeyer kín. Nhiệt độ của phản ứng thủy phân được kiểm soát bằng tủ sấy Ketong (Trung Quốc). Enzyme Protamex bị vô hoạt bằng cách đun cách thủy ở nhiệt độ $90^{\circ} \mathrm{C}$ trong 10 phút sau khi kết thúc phản ứng thủy phân. Lọc hút chân không Buchner với giấy lọc Whatman. No.1 được sử dụng để tách chất rắn không hòa tan và dịch lỏng. Lượng chất rắn còn lại trên giấy lọc được sấy khô đến khối lượng không đổi ở $100^{\circ} \mathrm{C}$ dùng để xác định hiệu suất thủy phân. Dịch lỏng qua giấy lọc được bảo quản ở $4^{\circ} \mathrm{C}$ dùng cho các phân tích tiếp theo.

\subsubsection{Khảo sát các yếu tố ảnh hưởng đến phản ứng thủy phân sụn khớp chân gà với xúc tác enzyme Protamex nhằm thu dịch axit amin}

Các yếu tố có ảnh hưởng lớn đến phản ứng thủy phân sụn khớp chân gà với xúc tác enzyme Protamex được lựa chọn để khảo sát dựa trên nghiên cứu của Bùi Viết Cường và cộng sự (Bui \& ctv., 2018; 2019): nhiệt độ phản ứng $\left({ }^{\circ} \mathrm{C}\right), \mathrm{pH}$ môi trường phản ứng, tỉ lệ enzyme (\%, so với cơ chất), thời gian phản ứng (phút) và tỉ lệ thể tích môi trường phản ứng (v/v). Mỗi thí nghiệm được lặp lại ba lần.

Ảnh hưởng của nhiệt độ phản ứng $\left({ }^{\circ} \mathrm{C}\right)$ : Nhiệt độ phản ứng được lựa chọn để khảo sát từ 30 - $80^{\circ} \mathrm{C}$ (khoảng cách giữa hai điểm khảo sát là $\left.10^{\circ} \mathrm{C}\right)$; $\mathrm{pH}$ môi trường phản ứng là $\mathrm{pH}$ tự nhiên của hỗn hợp sụn khớp chân gà và nước cất; tỉ lệ enzyme: $0,32 \%$; thời gian phản ứng: 20 phút; tỉ lệ thể tích môi trường phản ứng: $1 / 10(\mathrm{v} / \mathrm{v})$.

Ảnh hưởng của $\mathrm{pH}$ môi trường phản ứng: Khoảng pH môi trường phản ứng được lựa chọn để khảo sát từ $3-8$ (khoảng cách giữa hai điểm khảo sát là 1). Nhiệt độ phản ứng thích hợp được lựa chọn từ khảo sát trên, tỉ lệ enzyme: $0,32 \%$; thời gian phản ứng: 20 phút; tỉ lệ thể tích môi trường phản ứng: $1 / 10(\mathrm{v} / \mathrm{v})$.

Ảnh hưởng của tỉ lệ enzyme: Nhiệt độ phản ứng và $\mathrm{pH}$ môi trường phản ứng thích hợp từ các khảo sát trên được sử dụng để khảo sát ảnh hưởng của tỉ lệ enzyme đến phản ứng thủy phân sụn khớp chân gà. Tỉ lệ enzyme từ $0,02-0,82 \%$ (chênh lệch tỉ lệ enzyme giữa hai thí nghiệm: $0,1 \%$ ); thời gian 
phản ứng: 20 phút; tỉ lệ thể tích môi trường phản ứng: $1 / 10(\mathrm{v} / \mathrm{v})$.

Ảnh hưởng của thời gian phản ứng: Thời gian phản ứng: 10 - 80 phút được lựa chọn để khảo sát ảnh hưởng của thời gian phản ứng (khoảng cách giữa hai khảo sát là 10 phút). Nhiệt độ phản ứng, pH môi trường phản ứng, tỉ lệ enzyme thích hợp được lựa chọn từ các khảo sát trên, tỉ lệ thể tích môi trường phản ứng: 1/10 (v/v).

Ảnh hưởng tỉ lệ thể tích môi trường phản ứng: Nhiệt độ phản ứng, pH môi trường phản ứng, tỉ lệ enzyme, thời gian phản ứng thích hợp ở các khảo sát trên được sử dụng để khảo sát ảnh hưởng của tỉ lệ thể tích môi trường phản ứng $(\mathrm{v} / \mathrm{v})$. Tỉ lệ thể tích môi trường phản ứng được lựa chọn để khảo sát từ $1 / 6(\mathrm{v} / \mathrm{v})$ đến $1 / 30(\mathrm{v} / \mathrm{v})$ (chênh lệch thể tích môi trường phản ứng giữa hai khảo sát là $10 \mathrm{~mL}$ ).

\subsubsection{Các phương pháp phân tích}

Phân tích thành phần hóa học: Thành phần hóa học của sụn khớp chân gà (độ ẩm, lipid, protein và tro) được phân tích theo phương pháp chuẩn của cộng đồng phân tích (AOAC) (Horwitz, 2010).

Xác định hiệu suất thủy phân (Nguyen \& ctv., 2011; Bui \& ctv., 2017; Bui \& ctv., 2019): Hiệu suất thủy phân được xác định theo công thức $\mathrm{H}_{\mathrm{h}}=\left(\frac{\mathrm{M}_{\mathrm{i}}-\mathrm{M}_{\mathrm{r}}}{\mathrm{M}_{\mathrm{i}}}\right) \times 100 \%$. Trong đó, $\mathrm{M}_{\mathrm{i}}$ là lượng chất khô có trong sụn khớp chân gà $(\mathrm{g}), \mathrm{M}_{\mathrm{r}}$ là lượng chất rắn còn lại sau phản ứng thủy phân (g) và $\mathrm{H}_{\mathrm{h}}$ là hiệu suất thủy phân $(\%)$.

Xác định hiệu suất thu nhận nitơ axit amin: Nitơ axit amin của sản phẩm thô được xác định bằng phương pháp đồng được xây dựng bởi Pope và Stevens (Pope \& Stevens, 1939). Hiệu suất thu nhận nitơ axit amin được tính theo công thức $\mathrm{H}_{\mathrm{N} \text { - aa }}=\frac{\mathrm{M}_{\mathrm{N}} \text { - aa }}{\mathrm{M}_{\mathrm{pm}}} \times 100 \%$. Trong đó, $\mathrm{M}_{\mathrm{N} \text { - aa là }}$ lượng nitơ axit amin có trong sản phẩm thô thu được sau phản ứng thủy phân $(\mathrm{g}), \mathrm{M}_{\mathrm{pm}}$ là lượng nitơ protein có trong sụn khớp chân gà $(\mathrm{g})$ và $\mathrm{H}_{\mathrm{N} \text {-aa }}$ là hiệu suất thu nhận nitơ axit amin (\%).

Phương pháp xử lý số liệu: Phần mềm Minitab (Version 18, Minitab Inc, Pennsylvania State, USA) được sử dụng để phân tích phương sai ANOVA One-Way với mức độ tin cậy $95 \%$ cho sự khác biệt có ý nghĩa nhằm lựa chọn điều kiện tốt nhất cho từng yếu tố ảnh hưởng.

\section{Kết Quả và Thảo Luận}

\subsection{Thành phần hóa học của sụn khớp chân gà}

Trong thành phần hóa học của sụn khớp chân gà, độ ẩm chiếm phần trăm khá lớn $(62,12 \pm$ $1,39 \%$ ) và chất khô chiếm khoảng $1 / 3$ khối lượng. Thành phần hóa học của sụn khớp chân gà được trình bày ở Bảng 1 .

Bảng 1. Thành phần hóa học của sụn khớp chân gà

\begin{tabular}{lc}
\hline Thành phần & Phần trăm $(\%)$ \\
\hline Độ ẩm & $62,12 \pm 1,39$ \\
Lipid & $19,72 \pm 0,05$ \\
Protein & $13,34 \pm 0,08$ \\
Tro & $0,81 \pm 0,01$ \\
Thành phần khác & $4,01 \pm 1,50$ \\
\hline
\end{tabular}

Trong chất khô của sụn khớp chân gà, lipid chiếm phần trăm cao nhất $(19,72 \pm 0,05 \%)$; tiếp theo là protein với $13,34 \pm 0,08 \%$ và tro và các thành phần khác chiếm tỉ lệ thấp. Kết quả phân tích thành phần hóa học của sụn khớp chân gà trong nghiên cứu này có sự khác biệt so với nghiên cứu của Seyer và cộng sự (Seyer \& ctv., 1974). Ở nghiên cứu của Seyer và các cộng sự, độ ẩm chiếm rất cao $(82,85 \pm 1,42 \%)$, lipid chiếm tỉ lệ rất thấp $(0,29 \pm 0,72 \%)$, protein chiếm khá lớn $(11,78 \pm$ $0,28 \%)$ trong tổng khối lượng chất khô. Sự khác nhau về nguồn gốc nguyên liệu và phương pháp phân tích dẫn đến sự khác nhau về thành phần hóa học của sụn khớp chân gà trong nghiên cứu này so với nghiên cứu của Seyer và cộng sự. Sụn khớp chân gà trong nghiên cứu này có hàm lượng protein tương đối cao, là nguyên liệu thích hợp để thủy phân thu nhận axit amin.

\section{2. Ảnh hưởng của nhiệt độ phản ứng}

Nhiệt độ phản ứng là một trong những yếu tố quan trọng ảnh hưởng rất lớn đến tốc độ phản ứng thủy phân với xúc tác enzyme. Ảnh hưởng của nhiệt độ phản ứng đến $\mathrm{H}_{\mathrm{h}}$ và $\mathrm{H}_{\mathrm{N} \text {-aa }}$ amin được trình bày ở Hình 1 .

Nhiệt độ phản ứng trong khoảng khảo sát (30 $-80^{\circ} \mathrm{C}$ ) có ảnh hưởng đáng kể đến $\mathrm{H}_{\mathrm{h}}$ tuy nhiên không ảnh hưởng lớn đến $\mathrm{H}_{\mathrm{N} \text {-aa }}$. $\mathrm{H}_{\mathrm{h}}$ tăng trong khoảng nhiệt độ phản ứng từ $30^{\circ} \mathrm{C}$ dến $50^{\circ} \mathrm{C}$ và đạt giá trị cực đại $(43,06 \pm 10,46 \%)$ ở nhiệt độ $50^{\circ} \mathrm{C}$, tuy nhiên, nếu tăng nhiệt độ phản ứng $\mathrm{H}_{\mathrm{h}}$ 


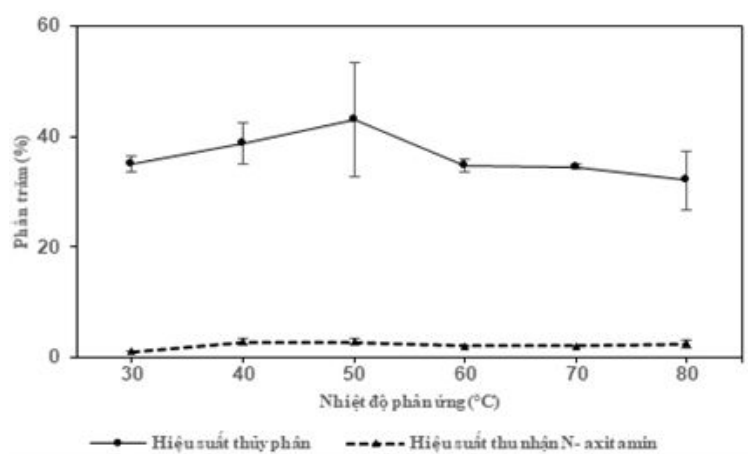

Hình 1. Ảnh hưởng của nhiệt độ phản ứng đến $\mathrm{H}_{\mathrm{h}}$ và $\mathrm{H}_{\mathrm{N}}$ - aa .

giảm do protein bị biến tính đông tụ làm cho khối lượng chất rắn còn lại sau quá trình thủy phân tăng. $\mathrm{H}_{\mathrm{N}}$ - aa có cùng xu hướng với hiệu suất thủy phân dưới ảnh hưởng của nhiệt độ phản ứng. Enzyme Protamex có nhiệt độ tối thích $35-60^{\circ} \mathrm{C}$ (Liaset \& ctv., 2003) do đó nhiệt độ phản ứng thấp hơn $35^{\circ} \mathrm{C}$ hoặc cao hơn $60^{\circ} \mathrm{C}$ sẽ làm cho $\mathrm{H}_{\mathrm{h}}$ và $\mathrm{H}_{\mathrm{N}}$ - aa giảm.

Phân tích sự khác biệt có ý nghĩa đối với $\mathrm{H}_{\mathrm{N} \text {-aa }}$ với sự ảnh hưởng của nhiệt độ phản ứng cho thấy ở nhiệt độ phản ứng $40^{\circ} \mathrm{C}$ có $\mathrm{H}_{\mathrm{N}}$ - aa cao nhất $(2,80 \pm 0,60 \%)$ và có sự khác biệt hoàn toàn so với $\mathrm{H}_{\mathrm{N}}$ - aa ở các nhiệt độ phản ứng khác. Vì vậy, nhiệt độ phản ứng $40^{\circ} \mathrm{C}$ được lựa chọn là nhiệt độ tốt nhất cho các khảo sát tiếp theo.

\section{3. Ảnh hưởng của pH môi trường phản ứng}

Hoạt độ của enzyme sẽ thay đổi cùng với sự thay đổi $\mathrm{pH}$ của môi trường do đó $\mathrm{pH}$ môi trường phản ứng có ảnh hưởng đáng kể đến $\mathrm{H}_{\mathrm{h}}$, Hh tăng khi pH môi trường phản ứng tăng trong khoảng khảo sát $3-8$. Ảnh hưởng của $\mathrm{pH}$ môi trường phản ứng đến $\mathrm{H}_{\mathrm{h}}$ và $\mathrm{H}_{\mathrm{N} \text {-aa }}$ được trình bày ở Hình 2.

$\mathrm{H}_{\mathrm{h}}$ tăng đều trong khoảng $\mathrm{pH}$ môi trường phản ứng từ 3 đến 6 , tăng mạnh trong khoảng $\mathrm{pH}$ môi trường phản ứng từ 6 đến 7 và đạt giá trị lớn nhất $(39,10 \pm 0,97 \%)$ tại $\mathrm{pH} 8 . \mathrm{H}_{\mathrm{N}}$ - aa đạt giá trị lớn nhất tại $\mathrm{pH} 4$ với giá trị 19,84 $\pm 3,07 \%$ và giảm nếu tiếp tục tăng $\mathrm{pH}$ của môi trường phản ứng. Điều này được giải thích do enzyme Protamex có $\mathrm{pH}$ tối thích đối với cơ chất sụn khớp chân gà là 4. $\mathrm{H}_{\mathrm{N}}$ - aa đạt giá trị lớn nhất ở $\mathrm{pH} 4$ với giá trị $12,23 \pm 2,43 \%$ và có sự khác biệt hoàn toàn so với $\mathrm{H}_{\mathrm{N}}$ - aa ở các $\mathrm{pH}$ môi trường phản ứng khác sau khi phân tích sự khác biệt có ý nghĩa. Giá trị

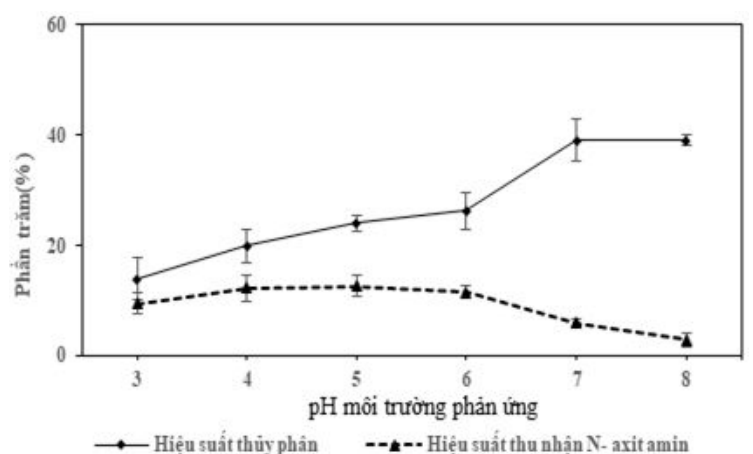

Hình 2. Ảnh hưởng của $\mathrm{pH}$ môi trường phản ứng đến $H_{h}$ và $H_{\mathrm{N}}$ - aa.

pH 4 được chọn cho khảo sát ảnh hưởng của tỉ lệ enzyme.

\section{4. Ảnh hưởng của tỉ lệ enzyme}

Trong điều kiện nồng độ cơ chất thích hợp thì vận tốc phản ứng thủy phân tî̉ lệ thuận với nồng độ enzyme. Hình 3 trình bày ảnh hưởng của tỉ lệ enzyme đối với $H_{h}$ và $H_{N}$ - aa .

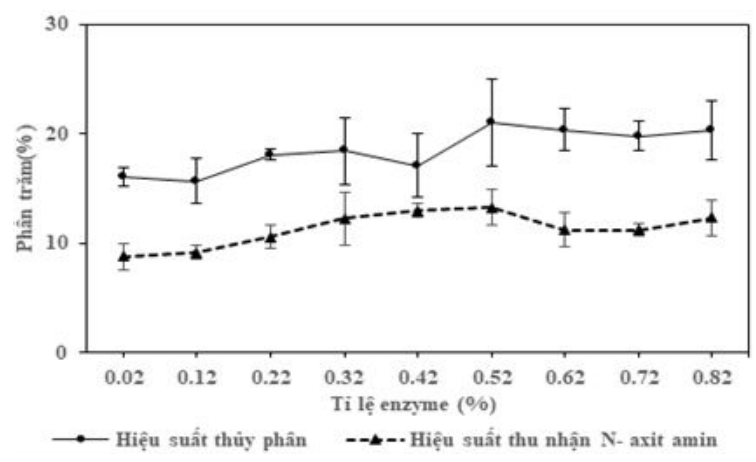

Hình 3. Ảnh hưởng của tỉ lệ enzyme (\%) đối với $H_{h}$ và $H_{N}$ - aa.

Khi thủy phân sụn khớp chân gà với tỉ lệ enzyme Protamex từ 0,02 đến $0,82 \%$ thì $\mathrm{H}_{\mathrm{h}}$ và $\mathrm{H}_{\mathrm{N}}$ - aa. Giá trị của $\mathrm{H}_{\mathrm{h}}$ tăng từ 15,68 $\pm 2,10 \%$ tại tî̉ lệ enzyme $0,12 \%$ đến $20,95 \pm 3,99 \%$ tại tỉ lệ enzyme $0,52 \%$. Khi tỉ lệ enzyme lớn hơn $0,52 \%$ thì cả $\mathrm{H}_{\mathrm{h}}$ và $\mathrm{H}_{\mathrm{N}}$ - aa không còn thay đổi đáng kể.

$\mathrm{H}_{\mathrm{N}}$ - aa đạt giá trị lớn nhất $(13,23 \pm 1,63 \%)$ ở tỉ lệ enzyme $0,52 \%$ và có sự khác biệt hoàn toàn so với các tỉ lệ enzyme khác, dựa trên kết quả phân tích sự khác biệt có ý nghĩa. Điều này được giải thích là tỉ lệ enzyme $0,52 \%$ là tỉ lệ enzyme tối thích ở các điều kiện khảo sát đã xác định để thủy phân sụn khớp chân gà. Do đó, giá trị $0,52 \%$ 
được chọn là tỉ lệ enzyme Protamex tốt nhất đối với phản ứng thủy phân sụn khớp chân gà.

\section{5. Ảnh hưởng của thời gian phản ứng}

Trong sản xuất công nghiệp việc xác định được thời gian phản ứng hợp lý có ý nghĩa quan trọng về mặt kỹ thuật lẫn tính kinh tế. Thời gian phản ứng không có ảnh hưởng lớn đến phản ứng thủy phân sụn khớp chân gà với xúc tác enzyme Protamex. Sự thay đổi của $\mathrm{H}_{\mathrm{h}}$ và $\mathrm{H}_{\mathrm{N}}$ - aa khi tăng thời gian phản ứng được trình bày ở Hình 4.

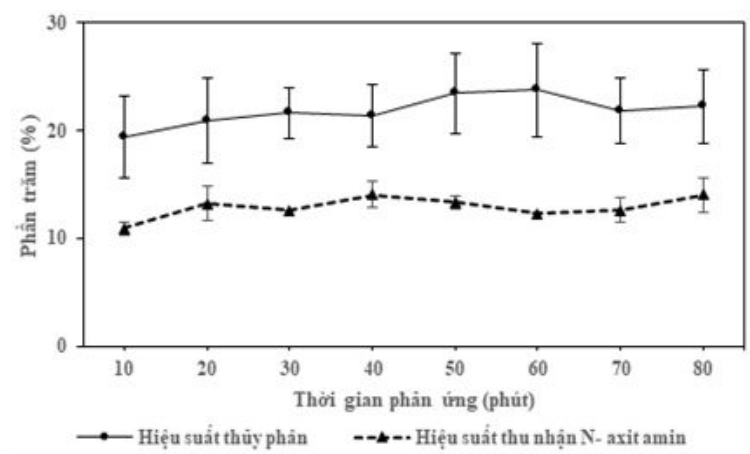

Hình 4. Ảnh hưởng của thời gian phản ứng đối với $\mathrm{H}_{\mathrm{h}}$ và $\mathrm{H}_{\mathrm{N}}$ - aa.

$\mathrm{H}_{\mathrm{h}}$ đạt giá trị lớn nhất $(23,80 \pm 4,34 \%)$ tại thời gian phản ứng là 60 phút và $\mathrm{H}_{\mathrm{N}}$ - aa đạt giá trị lớn nhất $(14,04 \pm 1,24 \%)$ ở thời gian 40 phút và không có sự thay đổi đáng kể khi tăng thời gian phản ứng. Có thể khi thời gian phản ứng tăng đến 60 phút, phản ứng thủy phân đã đạt được trạng thái cân bằng. Do đó, khi thời gian phản ứng lớn hơn 60 phút, $\mathrm{H}_{\mathrm{h}}$ và $\mathrm{H}_{\mathrm{N}}$ - aa không tăng. Bùi Viết Cường và cộng sự (Bui \& ctv., 2020) xác định $\mathrm{H}_{\mathrm{h}}$ và $\mathrm{H}_{\mathrm{N}}$ - aa đạt giá trị lớn nhất $49,89 \%$ và $67,62 \pm 1,30 \%$ với nhiệt độ phản ứng $60^{\circ} \mathrm{C}$; tỉ lệ enzyme $3 \%$ và thời gian phản ứng 60 phút khi tiến hành thủy phân sụn khớp chân gà với xúc tác enzyme papain nhằm thu axit amin. Sự khác nhau về $\mathrm{H}_{\mathrm{h}}$ và $\mathrm{H}_{\mathrm{N}}$ - aa trong nghiên cứu này so với nghiên cứu của Bùi Viết Cường và cộng sự là do sự khác nhau về nguyên liệu, xúc tác enzyme, phương pháp xác định nitơ axit amin và các yếu tố ảnh hưởng đến phản ứng thủy phân được lựa chọn để tiến hành khảo sát.

Kết quả phân tích sự khác biệt có ý nghĩa ảnh hưởng của thời gian phản ứng đối với $\mathrm{H}_{\mathrm{N}}$ - aa cho thấy $\mathrm{H}_{\mathrm{N}}$ - aa đạt giá trị lớn nhất tại thời gian phản ứng 40 phút với giá trị $14,04 \pm 1,24 \%$ và có sự khác biệt hoàn toàn với $\mathrm{H}_{\mathrm{N}}$ - aa ở các thời gian phản ứng khác. Thời gian 40 phút được chọn cho khảo sát tiếp theo.

\section{6. Ảnh hưởng của tỉ lệ thể tích môi trường phản ứng}

Nhìn chung, tỉ lệ thể tích môi trường phản ứng có ảnh hưởng lớn đến phản ứng thủy phân. $\mathrm{H}_{\mathrm{h}}$ và $\mathrm{H}_{\mathrm{N}}$ - aa tăng đáng kể khi tỉ lệ thể tích môi trường phản ứng tăng. Ảnh hưởng của tỉ lệ thể tích môi trường phản ứng đối với $\mathrm{H}_{\mathrm{h}}$ và $\mathrm{H}_{\mathrm{N}}$ - aa được trình bày ở Hình 5 .

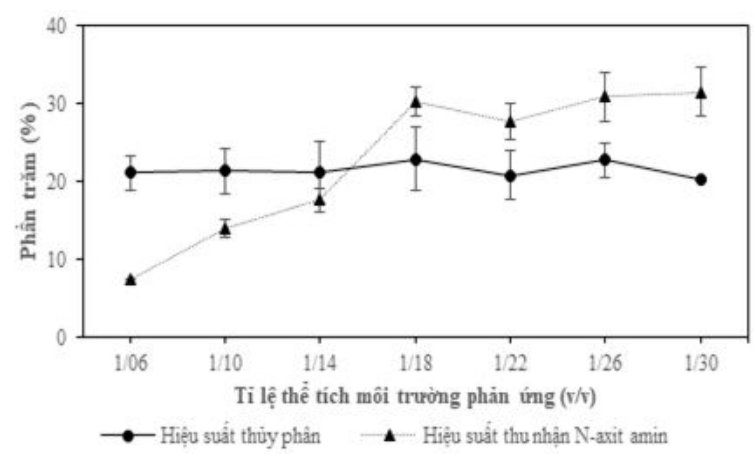

Hình 5. Ảnh hưởng của tỉ lệ thể tích môi trường phản ứng đối với $\mathrm{H}_{\mathrm{h}}$ và $\mathrm{H}_{\mathrm{N}}$ - aa .

$\mathrm{H}_{\mathrm{h}}$ và $\mathrm{H}_{\mathrm{N}}$ - aa đạt giá trị lớn nhất lần lượt là $22,76 \pm 2,26 \%$ và $31,56 \pm 0,09 \%$ tại tỉ lệ thể tích môi trường phản ứng lần lượt là $1 / 18(\mathrm{v} / \mathrm{v})$ và $1 / 26(\mathrm{v} / \mathrm{v})$. Hh có sự thay đổi không đáng kể đối với ảnh hưởng của tỉ lệ thể tích môi trường phản ứng, $\mathrm{H}_{\mathrm{N} \text {-aa }}$ tăng từ 7,58 $\pm 0,001 \%$ đến $30,25 \pm$ $1,86 \%$ tương ứng với tỉ lệ thể tích môi trường phản ứng tăng từ $1 / 6(\mathrm{v} / \mathrm{v})$ dến $1 / 8(\mathrm{v} / \mathrm{v})$. Khi tỉ lệ thể tích môi trường phản ứng lớn hơn $1 / 18$ (v/v) thì $\mathrm{H}_{\mathrm{N}}$ - aa không có sự thay đổi đáng kể có thể là do phản ứng thủy phân đã đạt trạng thái cân bằng. Bùi Viết Cường và cộng sự (Bui \& ctv., 2019) xác định $\mathrm{H}_{\mathrm{h}}$ và $\mathrm{H}_{\mathrm{N}}$ - aa đạt giá trị lớn nhất $25,97 \pm 0,71 \%$ và $40,9 \pm 0,89 \%$ với nhiệt độ phản ứng, $\mathrm{pH}$ môi trường phản ứng, tỉ lệ enzyme và thời gian phản ứng thích hợp lần lượt là $50^{\circ} \mathrm{C} ; 5$; $0,72 \% ; 20$ phút khi thủy phân sụn khớp chân gà với xúc tác enzyme flavourzyme nhằm thu axit amin. Sự khác nhau về $\mathrm{H}_{\mathrm{h}}$ và $\mathrm{H}_{\mathrm{N}}$ - aa cùng với điều kiện tốt nhất cho phản ứng thủy phân trong nghiên cứu này so với nghiên cứu của Bùi Viết Cường và cộng sự là do sự khác nhau về xúc tác enzyme được sử dụng và các yếu tố ảnh hưởng được lựa chọn để tiến hành khảo sát.

Phân tích sự khác biệt ý nghĩa cho thấy $\mathrm{H}_{\mathrm{N}}$ - aa 
tại tỉ lệ thể tích môi trường phản ứng $1 / 18$ (v/v) có sự khác biệt hoàn toàn so với các tỉ lệ thể tích môi trường phản ứng khác và đạt giá trị lớn nhất $(30,25 \pm 1,86 \%)$. Do đó, $1 / 18$ (v/v) được lựa chọn là tỉ lệ thể tích môi trường phản ứng tốt nhất.

\section{Kết Luận}

Trong nghiên cứu này, thành phần hóa học của sụn khớp chân gà được phân tích dựa trên phương pháp chuẩn của cộng đồng quốc tế (AOAC). Protein chiếm phần trăm khá cao trong chất khô của sụn khớp chân gà $(13,34 \pm 0,08 \%)$, do đó sụn khớp chân gà là nguyên liệu thích hợp để thủy phân thu nhận axit amin. Kết quả nghiên cứu cho thấy, $\mathrm{H}_{\mathrm{h}}$ và $\mathrm{H}_{\mathrm{N}}$ - aa đạt giá trị lớn nhất lần lượt $22,93 \pm 4,01 \%$ và $30,254 \pm 1,86 \%$ khi nhiệt độ phản ứng, $\mathrm{pH}$ môi trường phản ứng, tỉ lệ enzyme, thời gian phản ứng, và tỉ lệ thể tích môi trường phản ứng lần lượt là $40^{\circ} \mathrm{C} ; 4 ; 0,52 \% ; 40$ phút và $1 / 18(\mathrm{v} / \mathrm{v})$. Các đặc tính sinh học của dịch axit amin (kháng oxy hóa, kháng khuẩn,...), thành phần của dịch axit amin, khối lượng phân tử của các peptides sẽ là đối tượng nghiên cứu tiếp theo nhằm định hướng sản xuất thực phẩm cho con người và động vật.

\section{Tài Liệu Tham Khảo (References)}

Araújo, Í. B. D. S., Bezerra, T. K. A., Nascimento, E. S. D., Gadelha, C. A. D. A., anti-Gadelha, T., \& Madruga, M. S. (2018). Optimal conditions for obtaining collagen from chicken feet and its characterization. Food Science and Technology 38, 167-173.

Bui, C. V., Nguyen, M. N. T., Bui, D. X., \& Tran, T. V. T. (2018). Screening for optimal parameters of hydrolysis reaction of red meat of Sadar Orientalis with $\mathrm{NaOH}$ as a catalyst to obtain protein hydrolysis solution. Journal of Fisheries Science and Technology 2, 16-23.

Bui, C. V., Bui, X. D., \& Dang, M. N. (2020). Study on hydrolysis reaction of chicken cartilage using enzyme papain. Vietnam Trade and Industry Review 41, 2932 .

Bui, C. V., Nguyen, M. N. T., Nguyen, Q. V., Bui, D. X., \& Pham, M. T. (2019). Study on hydrolysis reaction of chicken cartilage using Falvourzyme. UED - Journal of Social Sciences, Humanities Education 9(4), 1-6.

Bui, D. X., Bui, C. V., Ngo, N. B. T., Pham, T. V., \& Pham, M. T. (2017). Research on the suitable parameters for hydrolysis reaction of red meat of striped tuna (Sarda orientalis) by using commercial protamex. Vietnam Journal of Science and Technology 55(5A), 108-115.
Horwitz, W. (2010). Official methods of analysis of AOAC International. Agricultural chemicals, contaminants, drugs (Volume I). Maryland, USA: AOAC International.

Jayathilakan, K., Sultana, K., Radhakrishna, K., \& Bawa, A. S. (2012). Utilization of byproducts and waste materials from meat, poultry and fish processing industries: a review. Journal of Food Science and Technology 49(3), 278-293.

Liaset, B., Julshamn, K., \& Espe, M. (2003). Chemical composition and theoretical nutritional evaluation of the produced fractions from enzymatic hydrolysis of salmon frames with Protamex ${ }^{\mathrm{TM}}$. Process Biochemistry 38(12), 1747-1759.

Luo, X. M., Fosmire, G. J., \& Leach Jr, R. M. (2002). Chicken keel cartilage as a source of chondroitin sulfate. Poultry Science 81(7), 1086-1089.

Mangino, E. (2019). AS/Canada projects slightly slower growth in Canadian chicken meat production for 2020. GAIN Report Number: CA19029. Retrieved April 1, 2020, from https://apps.fas.usda.gov/newgainapi/api/report/dow nloadreportbyfilename?filename $=$ Poultry $\% 20$ and $\% 20 \mathrm{P}$ roducts\%20Annual_Ottawa_Canada_8-29-2019.pdf.

Meeker, D. L. (2006). Essential Rendering - All about the animal by-products industry. Virginia, USA: National Renderers Association.

Nakano, T., \& Sim, J. S. (1995). A study of the chemical composition of the proximal tibial articular cartilage and growth plate of broiler chickens. Poultry Science 74(3), 538-550.

Nguyen, H. T. M., Sylla, K. S. B., Randriamahatody, Z., Donnay-Moreno, C., Moreau, J., Tran, L. T., \& Bergé, J. P. (2011). Enzymatic hydrolysis of yellowfin tuna (Thunnus albacares) by-products using Protamex protease. Food Technology and Biotechnology 49(1), 4855 .

Pope, C. G., \& Stevens, M. Fr. (1939). The determination of amino-nitrogen using a copper method. Biochemical Journal 33(7), 1070-1077.

Seyer, J. M., Brickley, D. M., \& Glimcher, M. J. (1974). The identification of two types of collagen in the articular cartilage of postnatal chickens. Calcified Tissue Research 17(1), 43-55.

Thureen, P. J. (2012). Neonatal nutrition and metabolism. Cambridge, UK: Cambridge University Press.

Wisuthiphaet, N., Klinchan, S., \& Kongruang, S. (2016). Fish protein hydrolysate production by acid and enzymatic hydrolysis. International Journal of Applied Science and Technology 9(4), 261-270. 